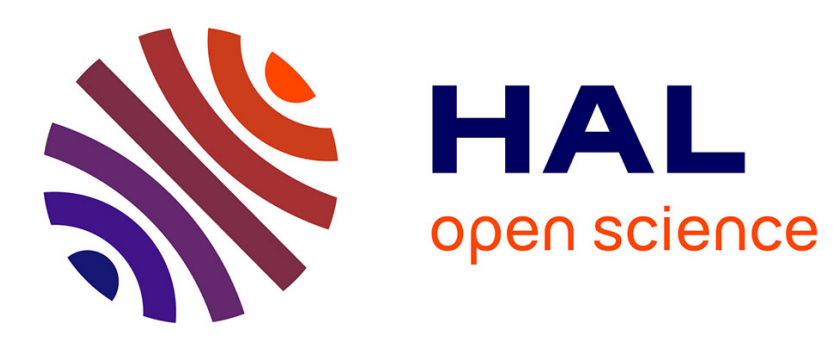

\title{
Bridging the Knowledge Divide in GCC Countries: The Role of Digital Technologies
}

Amer Al-Roubaie

\section{To cite this version:}

Amer Al-Roubaie. Bridging the Knowledge Divide in GCC Countries: The Role of Digital Technologies. 17th Conference on e-Business, e-Services and e-Society (I3E), Oct 2018, Kuwait City, Kuwait. pp.164-180, 10.1007/978-3-030-02131-3_16. hal-02274197

\section{HAL Id: hal-02274197 \\ https://hal.inria.fr/hal-02274197}

Submitted on 29 Aug 2019

HAL is a multi-disciplinary open access archive for the deposit and dissemination of scientific research documents, whether they are published or not. The documents may come from teaching and research institutions in France or abroad, or from public or private research centers.
L'archive ouverte pluridisciplinaire HAL, est destinée au dépôt et à la diffusion de documents scientifiques de niveau recherche, publiés ou non, émanant des établissements d'enseignement et de recherche français ou étrangers, des laboratoires publics ou privés. 


\title{
BRIDGING THE KNOWLEDGE DIVIDE IN GCC COUNTRIES: THE ROLE OF DIGITAL TECHNOLOGIES
}

\author{
Amer Al-Roubaie \\ College of Business and Finance, Ahlia University, Bahrain \\ aalroubaie@ahlia.edu.bh
}

\begin{abstract}
In recent years, emphasis in development studies has shifted toward knowledge creation and innovation that fosters economic growth and sustain development. Globalization is offering new opportunities, especially for developing countries, to acquire knowledge, information and skills for building capacity for development. Modern information and communication technologies (ICTs) are empowering countries to diversify the economic structure and enhance sectoral productivity through access to global markets. In this age of information, individuals, organizations and institutions are able to enhance communication and increase collaboration through social networking aimed at promoting innovation and improving global competitiveness. Digital technologies can be used to bridge the digital divide between rich and poor countries as a mechanism designed not only to increase connectivity and improve services, but also to facilitate innovation and capacity building for development. The aim of this paper is to examine the role that digital technologies plays in economic diversification in GCC countries. Digital technologies encourage investment in manufacturing production and knowledge creation, which stimulates linkages and support diversification. To this end, building capacity for digital economy could have a profound impact on the ability of these countries to speed up the process of socioeconomic transformation involving reduction of dependency on oil production.
\end{abstract}


Keywords: Globalization, digital technologies, e-services, knowledge creation, GCC countries

\section{INTRODUCTION}

In this age of information, digital services play an important role in societal transformation reflecting the contribution of modern technologies to building capacity for development. Recent advancement in information and communication technologies (ICTs), including high-speed internet, the smart phone and a wide array of applications accessible through android and the iPhone operating system (IOS), in addition to social media platforms, have empowered people to communicate across national boundaries making geographical locations no longer barriers to human interaction and business contact. Widening the scope of global connectivity has improved human understanding and increased information sharing aimed at bridging the digital divide and sustaining economic growth. Digital technologies are offering new opportunities, especially for developing countries, to deepen integration into the global markets and gain access to technology, knowledge, skills and information. Building capacity for ICTs could help countries speed up the process of development and strengthen the fundamentals for building digital society driven by linkage creation and knowledge acquisition.

The knowledge economy entails knowledge sharing and information dissemination through networking and inclusive access to all. Individuals, organizations and institutions will be able to communicate, collaborate and cooperate in sharing information and exchanging knowledge to enhance productivity and support innovation. Today, the world digital population exceeds more than 4 billion people reflecting the rapid advancement in ICTs within and across nations. Thus future sustainability will be influenced by investment in digital technologies that enhance connectivity worldwide. Building capacity for a digital society will require investment in digital literacy to empower people to gain entry global markets, access to which would facilitate 
knowledge acquisition, technology transfer and innovation diffusion. Bridging the development gap underscores the importance of digital literacy as a key means to increase national ability taking advantage of the new opportunities offered by the information age.

Making use of external knowledge not only reduces the cost of economic growth, but also helps developing countries to leapfrog several stages in development. In GCC countries, governments have responded to the structural decline in oil prices with urgency to diversify the economy and reduce dependence on the energy sector. A high degree of dependence on rents obtained from production and export of a limited number of commodities increases economic vulnerability by making the economy more sensitive to changes in global cyclical fluctuations. Digital technologies facilitate economic diversification by providing economies with multiple opportunities to enhance productivity and promote development. Building digital capacity strengthens the country's ability to acquire skills, create knowledge and share information - all of which are necessary for diversification the productive structure and reduction in dependency on the vicissitudes of global commodities markets.

The failure of the export-led growth model, driven by oil rents, has renewed the call for development alternatives to reduce the risk of high degree of export concentration and sustain economic growth. In the GCC countries, governments have responded by adopting long-term strategies aimed at diversifying productivity through knowledge creation and innovation. Investment in human capital, building ICT infrastructure, institutional reforms and deepening access in the global markets are among the core components of the new strategy. The aim of this paper is to examine the role that digital services play in knowledge sharing and innovation dissemination to speed up the process of development and foster economic growth. Building capacity for digital technologies fosters creation of linkages and strengthens the fundamentals for 
knowledge creation, technology transfer and innovation diffusion. This paper focuses on the challenges and opportunities facing socio-economic development in GCC countries.

\section{THE DIGITAL ECONOMY}

The term digital economy arises from the use of modern computers referring specifically to the use of the internet as a powerful device in communication and access to knowledge and information. The digital economy is a product of the information age in which networking and internet connectivity increased communications among people across national boundaries. The digital economy is defined by Oxford dictionary as an "economy which functions primarily by means of digital technology, especially electronic transactions made using the internet." "The transition to a digital economy can provide a boost to competitiveness across all sectors, new opportunities for business and entrepreneurial activity, and new avenues for assessing overseas markets. It also provides new tools for tackling persistent development and social problems." ${ }^{1}$ Today, e-services are having profound impact on our daily activities by increasing global interconnections and changing human understanding. Digital technologies are expected to shape the path of future trends by allowing individuals, organizations and institutions to share knowledge and information essential in effective decision-making and policy construction. The digital economy is also called the internet economy in reference to the extensive use of the internet in connecting people worldwide. Few would gainsay that the internet is a powerful tool for communication serving to link providers with consumers of digitally-driven information irrespective of national boundaries.

The 2016 World Development Report by the World Bank focuses on digital dividends outlining the importance of digital technologies in fostering economic growth, improved service delivery and expanding opportunities for people worldwide. Digital technologies have the power 
to foster growth and promote innovation across various sectors of the economy. It is estimated that the digital economy accounts for 8 percent of the GDP in OECD countries. In China digital economy reached $\$ 3.4$ trillion or 30.3 percent of the national GDP in 2016. This has been facilitated by the number of internet users in China accounting for 751 million out of the 3.89 billion internet users around the world in $2017 .^{2}$ Entrepreneurs in the South, including GCC countries, can benefit from the digital economy as a mechanism to communicate, acquire and absorb knowledge with the effect of diversifying the productive structure and bridging the development gap. In addition, the digital economy underpins e-government through facilitation of transactions with the public involving improvement in government delivery in a range of eservices contributing to a reduction in transaction costs serving, through public sector efficiencies, to promote sustainable economic growth. In the digital economies, individuals, business and institutions are expected to benefit not only from lower transaction costs but from greater access to new markets. Increasing connectivity enables firms to acquire technical and managerial skills essentials for running firms effectively and meeting international standards. Changes in the global economy are increasingly driven by digital technologies as mechanisms facilitating information exchange and data provision for use in market transactions, knowledge creation and innovation diffusion.

The growing interconnectedness of people, organizations and institutions represent the foundation of the digital economy. The globalization of economic activities in recent decades is a product of advancement in ICTs. Mercantile transactions generate value and create new business opportunities derived from the services provided by the internet. In this regard, the digital economy should be defined to represent broader meaning than just an internet economy. The 
digital economy increases the speed of making decisions and dissemination of information allowing organizations to execute tasks faster and keep pace with technological development and market changes. Such digital services are also useful for building long term business strategies to ensure competiveness in the future. New technologies, including mobile and cloud computing, as well as artificial intelligence, are bridging the gap between producers and consumers by providing information and facilitating marketing of products in various locations across the globe. All GCC countries are adopting new economic strategies aimed at restructuring the productive system and reducing dependency on energy production and export which represents the main driver of development.

The digital economy could have a positive impact on human development by improving the lives of people, especially in developing countries where basic needs remain inadequate to meet the challenges facing these populations. Providing access to people through digital technologies allow sharing knowledge and information among and within regions, Such shared knowledge and information can be used to improve decision-making and increase an individual's capabilities to participate in development as, for example, as entrepreneur. Digital technologies also increase government interaction with citizens to provide services and contribute to people needs across national boundaries. Digital technologies provide not only services using local resources, but also access to the rest of the world. Such connectivity provides new opportunities for developing countries to increase exports and gain access to international markets.

The new economy, also known knowledge-based economy, uses knowledge and innovation as an alternative to labor and capital in the traditional economy. The private sector assumes a more proactive role in market activates by giving young entrepreneurs the opportunity to participate in transforming the economy into a knowledge-based economy. These new 
generations of entrepreneurs can utilize digital technologies to enhance connectivity and create new business models based on knowledge sharing, collaboration and joint ventures with foreign firms. In this age of the internet, collaboration is particularly important to gain access to knowledge, skills and information for development. Private enterprises can be connected to multiple companies across different countries to participate in knowledge sharing, research and development, data gathering and in a number of highly complex market activities. The digitization of the economy not only is transforming businesses and societies, but also is promoting innovation and sustainable development.

The digital model is changing the workings of all aspects of society, including human interaction, policy construction, decision-making and demand for skills and job requirements. "Increased digitization and automation is leading to new types of jobs and employment, changing the nature and conditions of work and altering skills requirements, as well as affecting the functioning of the labor markets and the international division labour." ${ }^{3}$ In the digital economy, scientific research and knowledge dissemination will increase due to rapid economic transformations fueling business opportunities expected to create digital revolutions shaping the future during the course of the $21^{\text {st }}$ century. Economies will require increasing investment in building ICT infrastructure and strengthening connectivity in order to gain access to global markets. For developing countries in general and GCC in particular, innovation is linked to digital services making digital technologies important for obtaining social and economic benefit from ICTs.

During the last two decades China used the digital economy effectively to promote its etrade across the world. It is estimated that today China alones accounts for about 42 percent of the global e-commerce compared to less than one percent ten years ago. This is compared with 
the United States e-commerce at about 24 percent, down from 35 percent in 2005. Such rapid growth in China e-commerce reflects the importance of digital technologies in global integration and enhancing the country's capabilities to increase its share of trade worldwide. This made China a force to be reckoned with in digital technologies abroad and around the world. Payments through the internet by Chinese users increased from about 25 percent in 2013 to 68 percent in 2016 accounting for $\$ 790$ billion, 11 times more than that of the United States. China's billiondollar-valued startups account for 43 percent of the global value of "unicorn" companies worldwide reflecting the rapid progress that China was able to achieve in digital technologies. Such rapid growth in digital business is attributed to the commercialization of digital business as well as to governmental supports and incentives for investment in digital technologies. ${ }^{4}$

\section{INNOVATION AND KNOWLEDGE CREATION IN THE DIGITAL}

\section{ECONOMY}

The knowledge economy is driven by knowledge and innovation aimed at increasing productivity through sharing of information and creating new knowledge to support linkage creation and promote economic diversification. As an input in production, knowledge appreciates in value over time making investment in research and development essential to create new knowledge and linkages. However, restructuring the productive system to increase the knowledge content in production will require investment in education to increase the stock of human capital, to stimulate building ICT infrastructure, to spur development of a national innovation system and to foster institutional reform to support the transformation of the economy into a knowledge-based economy. Although some GCC countries, including Bahrain and the UAE, have been able to achieve high scores in global competiveness, ICT infrastructure, innovation and other knowledge-related indicators, very little progress has been realized so far to 
support rapid transformation to a knowledge economy. Education remains among the important challenges facing these countries to mint high quality graduates capable of making effective decisions, conducting research and development and providing managerial and technical leadership.

Information represents an important input for promoting innovation and development of new products. Digital technologies facilitates access to information worldwide which provides entrepreneurs, running small- and medium-size enterprises, access to new methods and new ideas that enhance creativity in a process of innovation resulting in the development of new products. Having information strengthens the ability of the individuals and organizations not only to improve production techniques, but also to create new knowledge. Digital technologies connect people across disparate geographies enabling them to share knowledge and collaborate in new projects of common interest.

Connectivity is improving the business environment through social connections among scientists, policy makers, academicians and businesses resulting in the sharing of ideas and provision of solutions to existing problems. Educational institutions, including universities, in the GCC countries should facilitate such social connectivity to increase cooperation and collaboration to share information and conduct joint research to find solutions to the challenges facing the region. Digital technologies provide connection and easy access to knowledge and information by digitally connecting people across the region to work together and support innovation. In this regard, digital literacy and digital skills is essential to strengthen the fundamentals for knowledge creation and innovation diffusion.

Knowledge can be created through the process of knowledge use in different forms. Engagement in organizational socialization, involving sharing information to convert tacit 
knowledge into explicit, can be undertaken to create commercial value and to improve competitiveness. Similarly, the process of externalization converts explicit knowledge into another form of codified knowledge ready for use by users. To this end, individuals and organizations create knowledge through sharing ideas, exchanging opinions and circulating information and knowledge among groups or employees to stimulate creativity and engage people in critical thinking for solving problems and development of new methods foster productivity. Knowledge occurs when information is reformulated and converted into knowledge.

In the knowledge economy, it is the human mind rather than physical assets that drive economic growth and increase productivity. In other words, development is largely influenced by the mental capital measured by the stock of human capital and the quality of higher education institutions. Produced capital and natural capital are important for building productive capacity for development; however, knowledge creation is a product of human intellectual activities. In this regard, knowledge-based development requires investment in people aimed at increasing the country's intellectual capabilities to create knowledge and promote innovation. Digital technologies provide the foundation for knowledge sharing and knowledge transfer. Using digital technologies enable individuals and organization to increase interactions and collaboration which promote the sharing of knowledge and help to produce new knowledge.

Building capacity for digital infrastructure to enhance digital literacy and increase communication is essential for knowledge creation. Educational institutions including universities need to restructure curricula and put more emphasis on learning instead of teaching to improve communication skills, working as a team, inculcate entrepreneurial skills, engender 
flexibility and hone computing skills. Lifelong learning is essential to ensure adaptability to technological changes and market conditions. It is estimated that human capital contributes $65 \%$ to the wealth in high-income countries compared only to $40 \%$ in poor countries. In the Middle East, the contribution of human capital to the total wealth accounted for 35\% in 2014 compared to $70 \%$ in OECD countries and $88 \%$ in United Kingdom. This makes investment in people the most valuable investment that a county can achieve to foster economic growth and support future sustainability. ${ }^{5}$

The production of new knowledge also facilitates the development of new innovation which results in converting ideas or tacit knowledge into value. In the age of digital technologies, organizations are able to strengthen socialization not only through networking but also through the "internet of things" allowing communication and dissemination of new ideas and the discovery of new knowledge absent human-to-human or human-to-computer interaction. In this respect, innovation and knowledge are interrelated and investment in knowledge creation could facilitate innovation diffusion across the economy.

\section{DIGITAL READINESS IN ARAB STATES}

Advancement in building Information and telecommunication Technologies (ICTs) infrastructure is measured by the ICT Development Index (IDI) illustrating a country's efforts to bridge the digital gap and deepen integration into the information age. The index measures the digital divide among nations in terms of capacity building for technological readiness and connectivity within and across nations. It reflects the level of connectivity infrastructure and the intensity use of ICT in society. IDI comprises three levels of ICT including ICT access, ICT use and ICT skills. (ITU, 2017, P. 26) With respect to the use of the internet, the percentage of individuals online in the total population varies from $91 \%$ in UAE to 57\% in Morocco and 38\% in Egypt. 
With the exception to the GCC countries, connectivity in most countries in the Middle East remains inadequate to stimulate development and close the digital divide. Among world's regions, Africa is far behind the rest of the world in terms of the use of the internet serving as an obstacle to its catching up with the rest of the world. Africa needs to build ICT infrastructure capable of connecting individuals, institutions and businesses across the continent in order to stimulate market activities and provide inclusive e-services to all.

Wide digital gaps extant among Arab countries underlie different levels of readiness in digital technologies among and within countries in the region. The term digital divide is used to measure the "differences in ICT development within and between countries, regions, socioeconomic groupings.“ (ITU, 2017, P. 50) ICTs empower societies to create knowledge, increase productivity and to bridge the digital divide that narrows the gap between rich countries and poor countries. The developing countries, including the Arab world, need to invest in ICT infrastructure if they have to speed up the process of catching up with the industrialized countries.

Table 1 illustrates the gap in technological readiness as measured by IDI ranging from 7.60 in Bahrain, 2.55 in Sudan, 1.58 in Djibouti and 1.64 in Comoros in 2017. On average IDI readiness in the Arab world measures 4.84 compared with 5.11 worldwide and 7.52 in developed countries. In 2017, the Arab world experienced the lowest average improvement in IDI among all world regions reflecting the inability of the region to narrow down the digital gap and benefit from the information revolution. In the global ranking, 13 out of the 19 Arab countries experienced drop by one or two places in 2017. With the exception of the GCC countries scoring above average in global rankings, the rest of the countries in the Arab region remained far below the world average. ${ }^{6}$ 
Table 1. Global and Regioals ICT indicators 2017

\begin{tabular}{|l|l|l|l|l|}
\hline Country & IDI & $\begin{array}{l}\text { Technological } \\
\text { readiness }\end{array}$ & $\begin{array}{l}\text { Individuals using } \\
\text { the internet as } \\
\text { of population }\end{array}$ & $\begin{array}{l}\text { Mobile phone } \\
\text { subscription per } \\
100 \text { people }\end{array}$ \\
\hline Iceland & 8.98 & 6.17 & 98 & 103.7 \\
\hline S. Korea & 8.85 & 5.54 & 90 & 118.5 \\
\hline Oman & 6.43 & 4.40 & 74 & 159.9 \\
\hline UAE & 7.21 & 5.82 & 91 & 187.3 \\
\hline Bahrain & 7.60 & 5.15 & 93 & 185.3 \\
\hline S. Arabia & 6.67 & 5.01 & 70 & 176.6 \\
\hline Kuwait & 5.98 & 4.33 & 82 & 231.8 \\
\hline Egypt & 4.63 & 3.26 & 38 & 111.0 \\
\hline Morocco & 4.77 & 3.69 & 57 & 126.9 \\
\hline Malaysia & 6.38 & 4.81 & 71 & 143.9 \\
\hline Qatar & 7.21 & 5.35 & 93 & 153.6 \\
\hline Jordan & 6.00 & 390 & 53 & 179.4 \\
\hline Nigeria & 2.60 & 3.15 & 47 & 82.2 \\
\hline Chad & 1.74 & 1.93 & 3 & 40.2 \\
\hline Africa & 2.64 & --- & 22 & 76.4 \\
\hline Arab States & 4.84 & --- & 44 & 111.0 \\
\hline Europe & 7.50 & --- & 71 & 114.9 \\
\hline Asia \& Pacific & 4.83 & --- & 50 & 101.5 \\
\hline The Americas & 5.21 & --- & 76 & ---- \\
\hline World & 5.11 & --- & 44 & 98.5 \\
\hline
\end{tabular}

Source: International Communication Union (ITU), (2017) Measuring the Information Society Report 2017, Vol. 1 (ITU: Geneva), World Bank, World Development Indicators 2017, World Economic Forum, The Global Competitiveness Report 2016/2017

Among the countries in the Arab region, Bahrain scored the highest IDI of 7.60 reflecting the government support for ICT development. The efforts by the government of Bahrain to transform its economy to a digital economy have borne fruit over the past 15 years. Today, Bahrain is among the most connected countries in the world providing internet services to all residents in the country. Building digital infrastructure will help the country to close the digital divide and speed up the process of economic diversification. Currently, the digital economy accounts for $8 \%$ of the economy of Bahrain compared to $5.1 \%$ in Kuwait, $4.3 \%$ in the UAE and 
less than $1 \%$ in both Oman and Qatar. (McKenzie p. 25) To be inclusive, digital technologies must include everyone in order to ensure equal access to all members of the society. Participation in the digital economy requires access to the internet as well as digital literacy to encourage people using e-services and benefit form digitization. In relation to the status of digital readiness in the Middle East the Gulf News point out:

"Despite the burgeoning dependence on internet, the Middle East is marred by high illiteracy rates that widen the digital divide. Across the Arab world, an estimated 57 million adults are illiterate. Another major problem is that many Arabs do not have access to proper infrastructure. Without solving these issues, any effort to minimize the digital divide may prove to be futile."7

In the Arab world, as elsewhere, governments serve as a major supplier of public services to citizens. To enhance public sector capability to deliver services to the public will require improved digital literary on the part of the general public. In turn, improving digital literacy will require governments to provide internet access to empower users with the skills needed to search and obtain information online. Digital literacy denoted ability of the general public to use digital tools in their daily activities. In the information society, digital inclusion is essential to ensure that all society members, including rural population, women and students, as well as businesses, will be able to have access to digital services. In the Middle East, only 6 percent of the population lives under smart governance. ${ }^{8}$

In the Middle East, digital technologies allow these countries to build new industries and expand productivity in the non-oil sector. In recent years, improvement in data processing and storage facilities have facilitated the emergence of what has come to be known as cloud computing. (UNCTAD: Information Economy Report 2013) By 2025, it is expected that most 
web services and ICT applications would be cloud delivered which require countries and organizations to enhance digital readiness to facilitate services through the cloud. Across the Arab world, digitization varies among countries which measure the digital gap among and within countries in the region. Countries such as Bahrain and UAE have invested heavily in digital technologies and, as a consequence, have been able to take advantage of the digital revolution and transform their societies into digital-based economies.

In a new society driven by smart technologies, which involve building digital infrastructure to improve the economy readiness ability to adopt and integrate into the information age, digitization requires new skills and training. Countries in the region must develop digital curricula to equip students with skills that match the demand for digital workforce. It requires rethinking education so as to ensure that students are able to operate technology and acquire the skills needed to use the web and search for information. Using the internet empowers individuals, institutions and organizations to make effective decisions and construct sound strategies aimed at improving efficiency and promoting innovation. Economic development entails an efficient allocation of resources designed to create a balance between and among sectors. To this end, collaboration, sharing knowledge and exchanging information through the internet accelerate the process of development and strengthen the country drive towards a knowledge-driven society.

Digital skills contribute to growth of SMEs by providing access to local, regional and global knowledge and information. In the knowledge economy, SMEs play critical role in productivity growth and knowledge creation through the use of digital services and internet connectivity. Thus curricula must address to need of the labor market by enhancing student capabilities to acquire such skills as critical thinking, technical and managerial skills, and 
problem solving. Familiarity with smart technologies underscores the importance of ICT literacy to empower users making use of digital services and strengthen global linkages.

In the Arab world, partnership and cooperation between the public and private sectors is essential to build capacity for digital economy. The role of the private sector in the digital economy is critical and, therefore, that both public and private institutions work together to build ICT capacity and narrow down the digital divide at both local and global levels. In a recent study by McKinsey and Company it is revealed that the Middle East region has realized 8\% augmentation in its digital potential. "Digital includes the foundations and underlying technologies and capabilities such as network and connectivity, computing, and storage, all of which enable the digitization of back-end processes as well as B2B and B2C interactions."

Countries of the GCC are making substantial efforts, investing heavily in ICT technologies, to increase the digitalization of their economies in order to catch up with the industrialized countries. "While the Middle East public sector entities are likely to spend over US15 billion in digital transformation enabling technologies in 2018, the GCC overall lags behind many developed countries in digital government. Countries in the region are not all at a similar stage of development with regard to government digitization levels." 10

\section{CLOSING THE DIGITAL DIVIDE}

The digital divide is a measure of the scale of the gap in the intensity use of ICT among "have" and "have-not" populations across or within countries. A digital divide is defined as an: "economic and social inequality with regard to access, use of, or impact of information and

communication technologies."11 The digital divide refers to the access of individuals and organizations to modern technologies, mainly ICT. It represents the socio-economic gap between and among countries in the use of the internet and digital technologies. 
Recent literature on development studies focus on the importance of digital technologies in knowledge creation, and innovation dissemination. Most developing countries are lacking to adequate knowledge to support development. Digital technologies facilitate access to global knowledge which can be used to stimulate linkages and increase productivity. In this age of the internet, access to knowledge and information has become easy with little or no cost. This could save developing countries substantial amount of resources both financial and technical. In recent decades, the Arab world, particularly the GCC countries, has made good progress in building capacity for ICT to improve connectivity and bridge the digital divide.

To ensure connectivity across and within social classes, development must be inclusive. Governments should ensure access by building ICT infrastructure capable of connecting all people at all locations within the state. Connecting people and regions via the internet allows policy-makers, on the one hand, and business managers and entrepreneurs, on the other, to formulate policies and/or plans and to make sound decisions aimed at meeting public and corporate objectives, respectively.

Rapid changes in technology entail continuous training and lifelong learning to improve technological learning and upgrade technical skills. In a connected world, people should be able to adapt to changing circumstances as well as to operate in different geographical locations. Acquiring skills in linguistics, critical thinking, problem solving, creativity and people management are critical for meeting $21^{\text {st }}$ century challenges. Investment in education and training enhances the national ICT readiness capabilities as well as increases the flexibility of the future work-force to adapt to technologically-induced changes in labor market demands.

Gender inequality among nations remains a matter of concern for many countries. Connectivity should be inclusive for narrowing the digital divide by providing equal opportunity 
to all without discrimination against social groups because of gender, color, disability and religion. Exclusion of women, for example, would weaken development initiatives designed to close the digital divide. Women account for half of the population and, therefore, excluding them reduces labor force participation and lowers growth. In developing countries, internet access is estimated to represent $41 \%$ or just about half of the access attained in developed countries. In the new economy, work is being done online out of home; such represents an opportunity for women to participate in the economy, especially in conservative societies, where women are restricted from working with men. Under such circumstances, providing digital skills for women will speed up the process of development and increase growth.

The digital economy provides new opportunities for developing countries to increase productivity, promote innovation and engage in global trade. Small- and medium-sized enterprises and young entrepreneurs benefit from the digital economy by getting easy access to global markets and, in turn, contribute to local development. Digital technologies allow small enterprise to cut cost and sell their products competitively in world markets. ICTs empower entrepreneurs, especially women, to engage in market activities which enhance productivity, create jobs and improve competiveness. However, developing countries need to enhance ICT readiness if they are to obtain full benefit from the digital technologies. Inadequate ICT infrastructure, which weakens connectivity to global markets, not only hinders development and broadens the digital divide, but also increases global inequalities. "The ability of countries and enterprises to exploit new digital resources will become a key determinant of competitiveness."12 In this regard, the educational system needs to contribute to the digitization of the economy by adapting curricula that facilitates labor market flexibility and provides students with the skills needed for participating in the information age. 
Connectivity, driven by modern ICTs, could have positive impact on development helping developing countries to foster economic growth and accelerate the process of socioeconomic transformation. Challenges facing these countries such as poverty alleviation, population growth, urbanization, pollution and lack of adequate public services can be met with the use of digital services. ICTs usually empower society to build capacity for development by providing opportunities for people to share information and work more effectively towards finding solutions to the problems facing them. Studies have showed that per capita income is positively related to IDI reflecting the importance of ICT technologies in promoting human development. Improvement in income per capita represents aggregate measure involving structural transformation within the productive system of the society. In this regard, building ICT infrastructure increases the ability of both public and private sectors not only to strengthen partnership and participate in joint projects, but also expand the country choices through access to regional and global markets. ${ }^{13}$

Digital technologies require special skills that workers need to acquire in order to be employed in the digital industry. Governments and educational institutions must ensure that the curricula used in teaching meet the need of labor markets and help workers adapt to the new technologies. The important challenges facing governments in developing counties is to close the skills gap by providing training for women to improve employability. Automation is replacing traditional jobs including bookkeepers, bank tellers, clerks and others. Empowering workers with new skills will be beneficial for both workers and the economy.

To make utilization of digital services effective, investment in digital literacy is prerequisite. Literacy in digital technologies facilitates connectivity among and within nations providing people and regions, particularly in isolated areas new opportunities, to gain access to 
external knowledge and information. Workers need to know how to use ICTs if bridging the gap to be closed. Poor areas lacking technical and financial resources to build ICT infrastructure, require governmental intervention in the form of investment in ICT infrastructure to provide access for all users within national boundaries.

In 2017, global sales online amounted to 2.3 trillion US\$ and it is estimated that the total sales will reach 4.88 trillion US\$ by the year 2021. In China alone an estimated 19 percent of all retail sales occurred via the internet. Revenues of Amazon.com from online sales amounted to $\$ 178$ billion in 2017 compared to US136 billion in 2016. In the Middle East, sales as a percentage of the total global e-commerce were 1.8 percent in 2016 -- the lowest among all world regions. ${ }^{14}$

The digital economy in GCC countries encourages economic diversification by providing SMEs with new opportunities to participate in market activities and obtain technical and managerial skills for improving their operations and meeting global standards. In recent years, globalization has increased outsourcing providing new opportunities, especially for SMEs in developing countries, to be linked to global value chains (GVCs) and participate in the global economy producing goods and services for multinational corporations. Digital technologies can also help SMEs expanding choices to acquire financing from external sources. Foreign firms will be willing to finance local enterprises to produce goods and services for exports. MNCs benefit from digital services by linking operations involving manufacturing of parts of final products efficiently in different countries as a function of factor costs.

\section{KNOWLEDGE INTENSITY AND DIGITAL SERVICES}

Digital technologies enhances the ability of an economy to produce high-tech products not only by improving the business environment to create knowledge and diffuse innovation, but also by 
providing global access, especially to local enterprises, to acquire skills, information and technology. Digitization facilitates cooperation and collaboration of productive enterprises both within and without the national boundary of an economy through sharing information and exchanging ideas. In developing countries, where knowledge is inadequate to stimulate linkages, acquiring knowledge from external sources could accelerate the process of knowledge creation. Technological learning through digital services enhances local firms' understanding and skills enabling them to produce high quality products at home. Digital technologies are important enablers offering new approach for local firms to collaborate with foreign firms and gain managerial and technical experiences which can be used to support local operations at home. As a consequence, local firms will be able to enhance technological learning not only to create knowledge in their organizations, but also to solve problems that local firms cannot accomplish on their own. Similarly, access to global knowledge is important for helping firms becoming innovative and capable of producing competitive products. Digital technologies facilitate continuous interaction between local firms and foreign markets searching for appropriate knowledge and suitable technologies to be utilized by domestic firms in production of goods and services. Internet connectivity is changing the way business and employees work and via sharing and communicating knowledge and ideas organizations are becoming innovative, creative and productive. To this end, organizations should integrate digital technologies into their strategies to ensure knowledge creation and global competitiveness.

The Economic Complexity Index (ECI) is a measure of the relative knowledge intensity in the economy. It explains the international variations in the content of knowledge in products exported by different countries as well as the inequality in incomes among nations. Knowledge intensity in products reflects the ability of the country to produce unique products very few 
countries can produce. Such uniqueness reflects a country's capabilities to create knowledge and promote innovation that strengthen the economy fundamentals to produce highly specialized products for exports. On the other hand, with respect to products with a low degree of sophistication, nearly all countries can easily produce. These are called ubiquitous products requiring very little knowledge such that many countries can produce them. However, countries that produce unique products are innovative and creative capable of producing and exporting goods even when the global economy flounders.

Table 2 lists countries ranked in accordance to the economic complexity index, product concentration index and diversification index for the year 2016. Switzerland, Japan and Singapore top the list of countries producing high degree of sophisticated products. In contrast, most countries in the Arab world fall in the category of ubiquity producing products with low levels of sophistication. The table also illustrates that the share of high-tech exports in total manufactured exports in all GCC countries is low compared to that of Japan, Singapore and Switzerland. This represents another important indicator that the economies of these countries remain producers of primary products with little or no knowledge is required in the production of goods and services.

Table 2. Economic Complexity Index (ECI), 2016 for selected countries

\begin{tabular}{|l|l|l|l|l|}
\hline Country & ECI & $\begin{array}{l}\text { Concentration } \\
\text { index }\end{array}$ & $\begin{array}{l}\text { Diversification } \\
\text { index }\end{array}$ & $\begin{array}{l}\text { High-tech } \\
\text { exports \% of } \\
\text { total exports }\end{array}$ \\
\hline Switzerland & 2.59625 & 0.288 & 0.645 & 26.4 \\
\hline Japan & 2.4687 & 0.141 & 0.400 & 16.7 \\
\hline Singapore & 2.12695 & 0.240 & 0.645 & 47.2 \\
\hline United States & 1.55257 & 0.100 & 0.244 & 18.2 \\
\hline Malaysia & 1.03133 & 0.174 & 0.442 & 43.9 \\
\hline Saudi Arabia & -0.355486 & 0.593 & 0.780 & 0.7 \\
\hline UAE & 0.241859 & 0.227 & 0.543 & --- \\
\hline Oman & -0.52902 & 0.506 & 0.753 & 4.3 \\
\hline
\end{tabular}




\begin{tabular}{|l|l|l|l|l|}
\hline Kuwait & -0.789111 & 0.627 & 0.823 & 0.1 \\
\hline Bahrain & & 0.32 & 0.678 & 1.5 \\
\hline Qatar & -0.525304 & 0.400 & 0.834 & 0.0 \\
\hline Egypt & -0.410868 & 0.154 & 0.581 & 1.3 \\
\hline Morocco & -1.09205 & 0.175 & 0.677 & 5.3 \\
\hline Jordan & -0.0100069 & 0.164 & 0.651 & 1.6 \\
\hline Algeria & -0.781585 & 0.489 & 0.816 & 0.2 \\
\hline
\end{tabular}

Source: https://atlas.media.mit.edu/en/rankings/country/neci/ United Nations, Human Development Report 2016, United Nationshttp://unctadstat.unctad.org/wds/TableViewer/tableView.aspx

\section{E-GOVERNMENT AND DIGITAL SERVICES}

In countries where the public sector is heavily involved in the economy and society, digital technologies could play an important role in transforming government services into productive activities aimed at improving educational and health services, increasing sectoral productivity, alleviating poverty, distributing income and promoting innovation. In the meantime, digital technologies represent new opportunities for the government to increase engagement in economic and social activities which are essential for fostering change and sustaining growth. People in isolated regions can access government services to stimulate market activities and create new job opportunities. Providing services through modern technologies could reduce costs of government delivery and improve efficiency. ICT can be used to empower SMEs by providing information on potential markets, commodity prices, online training and marketing. In doing so, the government will be able to cut back on costs of services provided for SMEs across sectors and regions. In peripheries where large rural populations live, e-services have the potential to increase productivity and improve living standards of millions of people outside of urban areas. 
Countries in the Arab world, especially in GCC region, are making efforts to diversify their economies and reduce dependency on oil production and exports. Digital technologies facilitate diversification through knowledge sharing, information dissemination and access to global markets. ICTs enhance government effectiveness to expand services and allocate productive resources in a productive manner. Having citizens able to interact and communicate with all levels of government facilitate knowledge sharing and stimulate linkages which encourage local enterprises to participate in market activities and diversify productivity.

Digital government is defined as the "employment of the internet and world-wide-web for delivering government information and services to the citizens." ${ }^{15}$ In countries where financial resources are inadequate to pay for government expenditures, the use of the internet could enhance the effectiveness of public services at affordable costs. E-government services offer new opportunities for people to acquire information and knowledge which encourage investment and create jobs. "Digital transformation will play a key role in modernizing public services, increasing service productivity and reducing labor intensity, increasing the level of satisfaction with and effectiveness of services, and increasing the openness of, trust in and engagement with government." 16

Online education has become a popular means for teaching and learning especially among those who live in isolated areas, the poor, women, and disadvantaged groups in society. Online educational services provide new opportunities for people to collaborate, cooperate and share ideas and knowledge aimed at enhancing capabilities and allowing greater connectivity with external markets. Collaborations among universities in research and development increase national capabilities to promote innovation and create new knowledge. Global collaboration not only facilities knowledge acquisition and transfer of new ideas, but also enhances the quality of 
teaching and learning. Communication among teachers and students makes teaching and learning more effective by providing students with opportunity to communicate with teachers outside school time.

Human development improves engagement in economic activities and contribution to economy. Digital technologies can increase choices and reduce costs of doing business which provides incentives for MSEs and young entrepreneurs to participate in market activities and create new employment opportunities. In other words, connectivity empowers people, including women and young entrepreneurs, to utilize, manage, share and create information aimed at increasing productivity, promoting innovation and sustaining development. Using digital technologies, SMEs have greater opportunities to expand operations and take advantages of new businesses in different markets. Some markets in GCC, including Bahrain, are small to stimulate linkages creation and encourage investment. Opening up regional markets will make it attractive for SMEs to expand operations through joint venture or production for exports. In this regard, regional integration among GCC whereby countries cooperate to reduce trade barriers will make it easier for SMEs to increase cross border trade and investment.

\section{CONCLUSION}

In recent decades, the emergence of the internet has had a profound impact on human society by bringing people closer together despite geographical distance and cultural differences. Today almost half of the world population uses the internet not only for sharing information and exchanging ideas, but also for promoting global understanding and creating linkages among and within nations. Building capacity for ICTs help the developing countries, in particular, to surpass several stages in their development. The digital divide has been identified with inadequate ICTs infrastructure to increase access to technology, information and skills. The challenge facing 
many developing countries is to close the digital divide by investing in ICTs. Connectivity is used to measure the availability of connections to the existing infrastructure of ICTs.

Digital technologies have become key driver of socio-economic transformation in the $21^{\text {st }}$ century underscoring the importance of investment in digital literacy and improving e-services to meet the challenges of economic diversification in the Arab region. Social networking and computer literacy are critical for knowledge sharing and technological learning aimed at empowering the region capabilities to close the digital divide and diversify the economic structure. The complex nature of economic development requires strengthening connectivity to enhance communications among various players and bridge the knowledge divide among and within countries of the region.

There are more than 90 countries offering on line services toady reflecting the role that digital technologies can play in promoting socio-economic progress. E-governments provide more inclusive and effective services that reach people in different locations. Public e-services not only improve public welfare and foster change, but also support democracy, by enabling more citizens to participate in decision making.

Digital technologies empower SMEs to increase participation in both local markets and the global economy. Accesses to global markets allow SMEs to acquire managerial and technical resources, which can be used to increase productivity and enhance competiveness. In other words, connectivity will enable SMEs to improve production processes and meet international standards. 
${ }^{1}$ UNCTAD, World Investment Report 2017, Investment and the Digital Economy, United Nations, Geneva, 156 (2017)

${ }^{2}$ Financial Tribunes. Retrieved from (https://financialtribune.com/articles/world-economy/77352/chinas-digital-economy-reaches-30-of-2016-gdp (May 7, 2018)

${ }^{3}$ UNCTAD, Information Economy Report 2017, United Nations, New York, XIV (2017)

${ }^{4}$ The McKinsey Global Institute, Digital China: Powering the Economy to global competitiveness. Retrieved from (https://www.mckinsey.com/global-themes/china/digital-china-powering-the-economyto-global-competitiveness (December 2017)

${ }^{5}$ World Bank, The Wealth of Nations, The World Bank, Washington (2018)

${ }^{6}$ International Telecommunication Union, (ITU) Measuring the Information Society Report Vol. 1, International Telecommunication Union, Geneva (2017)

${ }^{7}$ Gulf News Thinkers, Need to Bridge the Digital Divide. Retrieved from http://gulfnews.com/opinion/thinkers/need-to-bridge-the-digital-divide-1.1523204 (May 27, 2015)

${ }^{8}$ Deloitte, National Transformation in the Middle East: A Digital Journey, 17. Retrieved from https://www2.deloitte.com/content/dam/Deloitte/xe/Documents/technology-mediatelecommunications/dtme tmt national-transformation-in-themiddleeast/National\%20Transformation\%20in\%20the\%20Middle\%20East\%20\%20A\%20Digital\%20Journey.pdf

${ }^{9}$ The McKinsey Global Institute. Op. Cit., 4

${ }^{10}$ Deloitte, Op. Cit., 67

${ }^{11}$ Wikipedia https://en.wikipedia.org/wiki/Digital_divide

${ }^{12}$ UNCTAD, Op. Cit., XIV

${ }^{13}$ International Communication Union (ITU), Op. Cit., 50

${ }^{14}$ https://www.statista.com/statistics/239300/number-of-online-buyers-in-selected-countries/

${ }^{15}$ Wikipedia https://en.wikipedia.org/wiki/E-government

${ }^{16}$ OECD, Digital Government Strategies for Transforming Public Services in the Welfare Areas, Retrieved from http://www.oecd.org/gov/digital-government/Digital-Government-Strategies-WelfareService.pdf , 9 (2016) 